Relations industrielles

Industrial Relations

\title{
Marxian Analysis
}

\section{Earl F. Beach}

Volume 30, numéro 4, 1975

URI : https://id.erudit.org/iderudit/028664ar

DOI : https://doi.org/10.7202/028664ar

Aller au sommaire du numéro

\section{Éditeur(s)}

Département des relations industrielles de l'Université Laval

\section{ISSN}

0034-379X (imprimé)

1703-8138 (numérique)

Découvrir la revue

Citer cet article

Beach, E. F. (1975). Marxian Analysis. Relations industrielles / Industrial Relations, 30(4), 772-775. https://doi.org/10.7202/028664ar

Tous droits réservés (C) Département des relations industrielles de l'Université Laval, 1975
Ce document est protégé par la loi sur le droit d'auteur. L’utilisation des services d'Érudit (y compris la reproduction) est assujettie à sa politique d'utilisation que vous pouvez consulter en ligne.

https://apropos.erudit.org/fr/usagers/politique-dutilisation/ 


\section{COMMENTAIRES}

\section{MARXIAN ANALYSIS}

\section{Earl F. Beach}

The Marxian system has been universally proclaimed to be dynamic. ${ }^{1}$ It is therefore of some importance to discover that the analytical framework is static, that it cannot be modified easily, and that it has led to a very wrong conclusion which has been embedded in Marxian thinking.

Marx divided the value of a commodity 2 into three components, c for constant capital, $\mathrm{v}$ for variable capital, and $\mathrm{s}$ for surplus. The total of all such values makes up the total value for the economy, for which some important ratios are computed: s' for the rate of surplus value, $\mathrm{q}$ for the organic composition of capital, and $\mathrm{p}$ for the rate of profit.

The addition of such commodity values and their components for the whole economy is fully justified in arriving at some national accounts for past periods. It is not appropriate, however, for a short run analysis which Marx pretended to have.

Consider a change in $\mathrm{q}$, the organic composition of capital, which is a ratio of $c$ to the total of $c$ and $v$. An increase in $q$ is another name for mechanisation. When the baking industry is mechanized, the industry which makes baking machinery has its output increased. To ignore this relation in a «ceteris paribus » assumption is to use long run analytical method of comparing two equilibrium points. It is to compare two conditions of mechanisation, and not to analyse the effects of the process of mechanisation. Yet it is the short run conditions that Marx applies his analysis, as seen in the following passage ${ }^{3}$ :

«Between 1849 and 1859 , a rise of wages took place in the English agricultural districts... This was the result of an unusual exodus of

* E.F. Beach, Professor of Economics, McGill University, Montreal, Canada.

1 In the author's Preface to the first edition of Das Kapital he states that his objective is «to lay bare the economic law of motion of modern society. " Few have denied his claim to dynamic analysis.

2 In Das Kapital see Chapters 7,16 and 23 particularly. A good presentation is to be found in Chapter V of P.M. SWEEZY, The Theory of Capitalist Development (Monthly Review Press, N.Y., 1942).

3 Quoted by SWEEZY, p. 88. 
the agricultural surplus population caused by the demands of war, the vast extension of railroads, factories, mines, etc.... Everywhere the farmers were howling and the LONDON ECONOMIST, with reference to these starvation wages, prattled cuite seriously of a 'general and substantial advance.' What did the farmers do now ? Did they wait until, in consequence of this brilliant remuneration, the agricultural workers had so increased and multiplied that their wages must fall again, as prescribed by the dogmatic economic brain? They introduced more machinery and in a moment the laborers were redundant again in a proportion satisfactory even to the farmers. There was now 'more capital' laid out in agriculture than before, and in a more productive form. With this the demand for labor fell not only relatively but absolutely.»

Clearly Marx does not consider that this process of mechanisation might have affected the demand for labour elsewhere in the economy, might indeed have been in part the reason for the expansion in the factories which he mentions specifically. Yet these are year-to-year changes which need a form of analysis that is more suitable than the long run assumption that all adjustments have been completed.

There is another source of error. An increase of $c$ in the baking industry implies a much greater increase in output of the maching making industry. $\mathrm{c}$ is but the annual depreciation or cost of using machinery; the total cost of the machine is several times as great. The change in employment in the machine making industry is, therefore, something to be considered. 4

The damage to Marx's theoretical apparatus is substantial. 5 The Marxian Race 6 must be re-run. This Race was a conflict of the two great forces affection employment. "Accumulation 》 tended to increase employment, whereas mechanisation, or the changing organic composition of capital, tended to decrease employment. The result was a reserve army of unemployed which played a key role in limiting increases in wages. The process was, of course, a cyclical one. There is little doubt that the effects of mechanisation on employment cannot be analyzed

4 E.F. BEACH, «Automation in Perspective, » Applied Economics, 1971, 3, pp. 141-152.

5 This is really the heart of the Marxian economic system, as SCHUMPETER recognized. See J.A. SCHUMPETER, History of Economic Analysis (Oxford, 1954), p. 685 .

6 The concept of the Marxian Race was long a part of the German literature, related to the Compensation Controversy which followed the appearance of Das Kapital. It appeared in English but rarely. It is found in L.V. BIRCK, "Theories of Over Production, E. J., March, 1927 ; and in H.P. NEISSER, "'Permanent' Technological Unemployment, » A.E.R., March, 1942. 
by a «long run» technique, but must entail the changes that are a part of the process of mechanisation. Marx's analysis is clearly wrong. Furthermore, if the short run effects are expansionary rather than depressing, the Marxian system is badly wrecked. 7

It is not just the wreckage of the Marxian system that must be contemplated. Marx has been in goodly company 8 with his use of the long run partial equilibrium analysis for what is a short run problem. Economists generally have been guilty of this error in analyzing technological unemployment, as the history of the «naive argument $\gg$ shows.

This error can be illustrated easily. It is argued that it is naive to expect that the workers disemployed by machinery can be re-employed in making the machinery that displaced them because if this were possible, then there would be no saving in cost that was, presumably the reason for the introduction of the machinery. This form of argument is a long run comparison of costs, based on equilibrium relations. But it is well known that partial equilibrium analysis tells us nothing about

7 The meaning of Marx's accumulation is not exactly clear. If it is simply putting profits into capital goods, with no increase in the money supply, we are in a Hicksian capital shortage world. See BEACH, "Hicks on Ricardo on Machinery, » E.J., Dec. 1971, and J.R. HICKS, Capital and Time, especially Chapter X (Oxford, 1973). If, furthermore, there is some hoarding entailed in the progress, then the act of accumulation is deflationary, and does not expand employment. For the makers of cyclical models, this might imply simply that they interchange the active forces - what a sad comment on the state of economic theory - but the mechanism would then not work because mechanisation, by replacing variable capital, is supposed to reduce surplus value and hence profits, which are the source of accumulation. Marx is now standing on his head, but the disruption spreads much further!

8 E.F. BEACH, «A Native Argument, 》 RI/IR, Vol. 29, No. 2, pp. 403-5. Samuelson approaches this matter somewhat differently, but he also uses long run analysis for a short run question. See «Wages and Interest: A Modern Dissection of Marxian Economic Models, » A.E.R., December 1957, reprinted as Chapter 29 of The Collected Papers, Vol. 1. The matter of expanded reproduction he discusses under «Steady Growth»: "Apparently Marx did not have the time to perfect his «expanded reproduction»» model in which investment and growth take place. Modern techniques make such analysis a simple task. I retain the fixed proportions assumption and take up the natural case where, instead of being geared to a stationary level, the economic system is geared to steady growth. This necessarily means steady geometric or exponential growth at uniform percentage rate...» Yet he proceeds to discuss specifically «The Reserve Army of the Unemployed. : With these «modern tools of analysis» he concludes that «the Marxian notions do not achieve the desired goal of 'explaining the laws of motion or of development of the capitalistic system. » One could wish that his (Samuelson's) analysis was more convincing. 
the process of moving from one point to another. It can give us no information, therefore, about the speed of the change. ${ }^{9}$

Alternatively, consider the process of mechanising a particular industry. Every year, new machines are introduced into the said industry. Now suppose that the process of mechanisation is speeded up; clearly there will come a time when those disemployed from the one industry will not suffice for the needs of the machine making industry, and there will be a shortage of labour.

\section{THE CANADIAN INDUSTRIAL STRATEGY}

\section{A COMMENT}

\section{Arthur W. Donner \\ and}

Fred Lazar

\section{A FRAMEWORK FOR INDUSTRIAL POLICY MAKING}

The concept of an industrial strategy for Canada suggests a set of deliberate long-run policies aimed at affecting the fundamental structure of Canadian industry. It tends to emphasize deliberate and active government involvement.

In actual fact, the changes which do take place in the structure of our economy seldom stem from government actions aimed at achieving such long-term objectives. Important changes often evolve gradually, in an incremental and adaptive fashion, in response to particular shortterm objectives. The difficulty with this gradual process is that the longrun changes which may be traced to government action often take place primarily as residual side effects of individual short-term measures. What is more, the short-term government objectives themselves are often crisis oriented, originating with the need for immediate action to remedy particular problems.

9 It is interesting that the report of the U. S. National Commission on Technology, Automation, and Economic Progress, Technology and the American Economy (1966) starts on this theme. Chapter one bears the title: "The Pace of Technological Change, » and yet the analysis of the report throws no light on the matter, being limited to the long run analytical approach, and not considering any investment which would normally be associated with it, increasing in volume when the pace increases. 